Berkala Ilmu Perpustakaan dan Informasi, Vol. 16, No. 1, Juni 2020, Hal. 127-141

DOI: $10.22146 /$ bip.v16i1.72

ISSN 1693-7740 (Print), ISSN 2477-0361 (Online)

Tersedia online di https://journal.ugm.ac.id/v3/BIP

\title{
Teori kritis terhadap analisis sitasi untuk kajian kuantitatif sains dan evaluasi kinerja riset
}

\author{
Yaniasih \\ Fakultas Ilmu Komputer, Universitas Indonesia \\ Kampus Universitas Indonesia Depok, Jawa Barat, 16424 \\ e-mail: yaniasih@ui.ac.id,yani008@lipi.go.id
}

Naskah diterima: 6 Februari 2020, direvisi: 5 Mei 2020, disetujui: 10 Mei 2020

\begin{abstract}
ABSTRAK
Pendahuluan. Evaluasi kinerja riset dan kajian kuantitatif sains menggunakan sitasi sebagai indikator utama. Banyak kritik terhadap analisis sitasi sejak digunakan setengah abad lalu, namun belum berhasil membawa perubahan konsep dan metode baru. Makalah ini bertujuan melakukan telaah kritis dan mengajukan pendekatan baru dalam analisis sitasi.

Metode penelitian. Pengumpulan data dan analisis menggunakan kerangka metodologi teori kritis kontemporer. Data yang dikumpulkan adalah publikasi mengenai analisis sitasi dari basis data Google scholar, Microsoft academic search, dan Garuda Ristekdikti, serta dilengkapi dengan pengalaman penulis.

Data analisis. Metadata dan konten publikasi ditelaah secara kritis sedangkan pengalaman digunakan sebagai sudut pandang dalam memperkaya penelaahan.

Hasil dan Pembahasan. Hasil telaah memetakan kekurangan dari berbagai aspek yaitu (1) paradigma positivisme yang digunakan ternyata tidak berhasil mencapai tujuannya; (2) metode menghasilkan analisis yang kurang valid; serta (3) isu etika peneliti dan bias ideologi dalam implementasi.

Kesimpulan dan Saran. Solusi dan rekomendasi tindak lanjut yang diusulkan adalah perubahan metode analisis sitasi dari pengukuran sederhana data bibliografi ke arah analisis teks dan konteks sitasi berbasis pendekatan ilmu komputer dengan teknikpemelajaran mesin.
\end{abstract}

Kata Kunci: analisis sitasi; teori kritis; pemelajaran mesin

\begin{abstract}
Introduction. Citation is the main indicator in research performance evaluation using the quantitative approach. There have been many criticisms of citations since they were used half a century ago, but they have not yet succeeded in bringing new concepts and methods. This paper aims to criticize and propose a new approach to citation analysis.

Data Collection Method. A contemporary critical theory methodology was adopted as a framework to collect and analyze the data. Scientific publications related to citation analysis was collected from several databases such as Google scholar, Microsoft academic search, dan Garuda Ristekdikti. Analysis Data. Publications data were critically reviewed and analyzed narratively by using open coding.

Results and Discussions. The results mapped the lack of citation analysis form various aspects: (1) criticism of the positivist paradigm which did not succeed in achieving its objectives, (2) criticism of methods that produce invalid results, and (3) criticism of ethical issues of the researcher and bias in implementation. The proposed solution and recommendation is to change the citation analysis method from a simple measurement of bibliographic data to text and context analysis based on a computer science approach (machine learning techniques).
\end{abstract}


Conclusion. This new method has the potential to be developed within the framework of quantitative in Science and Technology studies to overcome existing criticisms. Subsequent multidisciplinary studies are needed to lay a strong philosophical and technical foundation particularly in applying the in-text citation analysis method for evaluating research performance in accordance with the Indonesian context.

Keywords: citation analysis; critical theory; machine learning

\section{A. PENDAHULUAN}

Analisis sitasi merupakan salah satu topik kajian kuantitatif sains seperti metode bibliometrik, informetrik, atau sainstometrik. Pertumbuhan publikasi yang sangat besar dan perkembangan teknologi kecerdasan buatan (artificial intelligence/AI) terutama pemelajaran mesin (machine learning), mengantarkan kajian ini berkembang dalam tiga dimensi utama yaitu manusia/lembaga, teks dokumen publikasi, dan konten/konsep (Leydesdorff \& Milojevic, 2015). Setiap dimensi fokus pada sumber data dan metodologi pendekatan disiplin ilmu tertentu, namun tetap saling terkait sehingga membentuk kajian interdisiplin (Gambar 1). Teori sitasi berhubungan dengan manusia dan muncul sebagai bagian dari etika ilmu pengetahuan sejak awal sains terbentuk (Merton, 1942). Di sisi lain, sitasi dituliskan sebagai bahasa simbol yang memiliki makna (konteks) dalam dokumen publikasi. Sebagai simbol, memungkinkan untuk dilakukan pengukuran dan kalkulasi (De Bellis, 2010). Makna dari konteks sitasi dalam teks sangat terkait erat dengan bahasa dan diskursus. Konteks ini mengandung berbagai informasi konten termasuk konsep, teori, motivasi, bahkan sentimen dari penulis (White, 2004). Perspektif ilmu komputer dapat memperkuat analisis diskursus dalam teks sitasi melalui berbagai pendekatan ilmu seperti pengolahan bahasa alami (natural language processing/NLP) dan pemelajaran mesin.

Kajian analisis sitasi berkembang pesat namun terus memunculkan kontroversi. Sitasi yang selama ini dianalisis adalah jumlah sitasi dalam daftar pustaka atau referensi teks publikasi. Metode ini dinilai kurang valid karena hanya mengukur kuantitas bukan kualitas sitasi yang dilihat dari dampak nilai dan fungsinya. Kontroversi yang lain terkait bias nilai dan ideologi dalam pemanfaatan analisis sitasi untuk evaluasi kinerja riset seperti pemeringkatan individu dan indeksasi jurnal. Analisis sitasi yang saat ini ada, sangat dipengaruhi oleh basis data yang disediakan oleh industri penerbitan dan pengukuran (publisher and counting house) seperti Elsevier dan Clarivate analytics. Perusahaan-perusahaan ini sangat mendominasi, menyitir dan dicurigai lebih bertujuan terhadap kepentingan bisnis daripada ilmiah (Kinouchi, 2014; Buranyi \& McKenzie, 2017; Tennant, 2018). Analisis sitasi berbasis data komersial semakin menguntungkan negara maju baik dari sisi ilmiah dan bisnis. Sementara negara-negara berkembang hanya menjadi pasar yang harus membeli data dengan harga berlangganan yang mahal. Ditambah lagi dengan masih digunakanya paradigma analisis sitasi yang sekarang, mereka mengalami kesulitan untuk mendapatkan manfaat yang sama dengan negara maju.

Kritik dan perubahan paradigma baru terhadap analisis sitasi untuk perkembangan ilmu yang lebih demokratis pun diajukan, namun kurang terdengar. Metode lama terus digunakan dalam riset dan publikasi yang ada, baik di tingkat internasional maupun nasional. Makalah ini bertujuan untuk melakukan telaah kritis terhadap analisis sitasi khususnya kritik terhadap konsep, metode, dan implementasi sosial, serta mengajukan rekomendasi tindak lanjut untuk perbaikan kajian kuantitatif sains dan evaluasi kinerja riset khususnya untuk diterapkan di Indonesia. Penulis menggunakan paradigma teori kritis dari pendekatan filsafat ilmu pengetahuan dalam metodologi penelitian.

Di Indonesia, analisis sitasi banyak berkembang dalam disiplin ilmu perpustakaan dan informasi. Sebagian besar publikasi memanfaatkan metode yang sudah mapan untuk menganalisis data publikasi di Indonesia. 
Observasi penulis menunjukkan sangat sedikit sekali publikasi (kurang dari 10 dokumen) yang fokus membahas sitasi dari perspektif filosofi, sosiologi, maupun ilmu komputer. Lebih sedikit lagi kajian yang melakukan telaah kritis untuk memperbaiki metodologi yang ada dalam konteks yang sesuai dengan kondisi di Indonesia. Riset dan produksi literatur di bidang ini sangat diperlukan untuk memperkuat landasan filosofis, teori, dan metodologi analisis sitasi. Kebutuhan ini penting dan mendesak karena analisis ini sudah diimplementasikan secara resmi oleh pemerintah dan mempengaruhi hajat hidup orang banyak.

\section{B. TINJAUAN PUSTAKA}

\section{Paradigma riset berbasis teori kritis}

Metodologi merupakan salah satu komponen utama dalam riset ilmiah. Metodologi sangat berkaitan dengan paradigma riset yang dibagi menjadi beberapa kategori yaitu positivisme, post-positivisme, konstruktivismel interpretasisme, transformasisme, dan pragmatisme. Metode teori kritis termasuk kategori transformasisme karena bertujuan untuk melakukan perubahan walaupun ada juga yang menjadikanya kategori paradigma sendiri (Vosloo, 2011; Źukauskas, Vveinhardt, \& Andriukaitienè, 2018).

Tujuan teori kritis adalah untuk memberikan pencerahan, membuka ketersilauan yang membutakan terhadap kenyataan sebenarnya, dan membebaskan manusia dari ideologi yang memanipulasi termasuk dalam ilmu pengetahuan yang berkedok rasionalisme modern (Bernstein, 1991; Magnis-Suseno, 1992; Wisri \& Mughni, 2016). Teori kritis bertentangan dengan positivisme yang menganggap ilmu pengetahuan dibangun berdasarkan obyektivitas, bebas nilai, dan netral. Para tokoh teori kritis meyakini bahwa pengetahuan tidak ditentukan oleh obyek melainkan konstruksi dari subyek yang menghasilkan pengetahuan (ilmuwan)(Kodir, 2016). Teori yang dihasilkan tidak selalu mengarah pada kebenaran namun pada kepentingan pihak penguasa. Salah satu tokoh, Habermas, mengungkapkan hubungan antara pengetahuan dan kekuasaan sebagai suatu bentuk politik epistemologi. Habermas menyatakan adanya kepentingan-kepentingan yang membentuk pengetahuan sehingga kita harus waspada terhadap klaim obyektivitas pengetahuan(Iwan, 2014).

Penggunaan teori kritis untuk menganalisis analisis sitasi menurut penulis tepat karena metode analisis sitasi saat ini sudah mapan dan digunakan luas namun menyisakan banyak kontroversi. Teori kritis mengajak untuk menelaah kembali dan membuka kebenaran yang ada, sehingga konsep dan metode analisis sitasi tidak langsung dianggap sudah benar tanpa ada kritik dalam penggunaanya. Apalagi, metode ini digunakan untuk kajian sains dan evaluasi kinerja riset sehingga berpengaruh terhadap kebijakan riset nasional dan hajat hidup banyak orang terutama akademisi dan peneliti.

\section{Hubungan analisis sitasi, kajian kuantitatif sains, dan evaluasi kinerja riset}

Analisis sitasi, kajian kuantitatif sains, dan evaluasi kinerja riset memiliki hubungan yang erat. Kajian kuantitatif sains merupakan bagian dari kajian sains dan teknologi yang didominasi perspektif bidang ilmu perpustakaan dan informasi, matematika dan statistik, serta ilmu komputer. Metadata dan konten teks lengkap dokumen publikasi merupakan sumber data utama kajian kuantitatif sains. Sebagian besar metode kajian ini menggunakan sitasi sebagai variabel utama yang dianalisis. Dari sinilah analisis sitasi berkembang dan menjadi topik dominan dalam kajian kuantitatif sains. Sitasi juga menjadi indikator utama dalam semua metrik pengukuran kinerja riset. Metrik-metrik yang ada pun mengadopsi teknik-teknik kajian kuantitatif sains.

\subsection{Kajian kuantitatif sains}

Kajian sains dan teknologi (science and technology study/STS) merupakan kajian yang membahas bagaimana masyarakat, politik dan budaya saling mempengaruhi dengan riset ilmiah maupun inovasi teknologi. STS melibatkan tiga disiplin utama yaitu antropologi, sosiologi, dan sejarah. STS mulai 
berkembang sejak tahun 1940an dengan salah satu tokohnya adalah Robert Merton (1942). Robert mengenalkan pendekatan empiris dalam kajian sains sebagai bidang interdisiplin. Merton pula yang pertama menyatakan perlunya pengukuran kuantitatif untuk mengukur perkembangan dan stratifikasi sains. Pada tahun 1960an, konsep Merton beresonansi dengan Derek Price yang meletakan dasar bagi perkembangan kajian kuantitatif sains (Wyatt, Milojević, Park, \& Leydesdorff, 2015). Kajian kuantitatif sains dianggap sebagai bagian kecil dari STS dan memiliki perkembangan yang terpisah (memiliki jurnal sendiri dan kepakaran sendiri). Hubungan kajian kuantitatif sains dan STS kembali muncul terkait perkembangan jumlah produksi riset dan teknologi yang sangat besar, mengantarkan kajian ini pada analisis jaringan sains yang dapat dapat menggambarkan evolusi sains secara kuantitatif yang mendukung STS (Leydesdorff \& Milojevic, 2015).

Kajian kuantitatif sains bertumpu pada beberapa metode pengukuran (metrik) seperti bibliometrik, sainstometrik, dan informetrik. Setiap metrik memiliki fokus masing-masing, namun ada beberapa bagian yang tumpang tindih. Bibliometrik identik dengan analisis terhadap bahan pustaka seperti buku, jurnal, dan sitasi menggunakan analisis statistik secara umum. Bibliometrik menjadi domain kajian bidang ilmu informasi dan perpustakaan. Sainstometrik, selain mengkaji publikasi dan hasil-haril riset lainnya, juga mengkombinasikan dengan berbagai data terkait perkembangan sains seperti sumber daya manusia, fasilitas, ekonomi dan kebijakan. Dalam menganalisis dokumen publikasi, sainstometrik kerap kali menggunakan konsep bibliometrik. Adapun informetrik mengkaji aspek kuantitatif dari semua bentuk informasi tidak hanya yang terkait sains (Sengupta, 1992).

\subsection{Analisis sitasi}

Analisis sitasi adalah kajian terhadap jumlah, pola, dan grafik dari sitasi dalam dokumen khususnya publikasi buku, prosiding, dan artikel jurnal. Atribut dalam dokumen publikasi dapat dianalisis menggunakan sitasi antara lain dikaitkan dengan penulis, penerbit, jurnal dan juga konteks dalam teks (Garfield, 1983). Metode bibliometrik, dikenal istilah cocitation dan bibliographic coupling untuk menganalisis jaringan sains berdasarkan sitasi. Bibliographic coupling digunakan untuk menganalisis dokumen yang mengutip sedangkan co-citation digunakan untuk menganalisis dokumen yang dikutip. Menggunakan dua pendekatan ini dapat dibangun peta jaringan sains berdasarkan hubungan antar atribut dokumen (Cobo, LopezHerrera, Herrera-Viedma, \& Herrera, 2011). Gambar 2 menunjukkan model hubungan sitasi, co-citation dan bibliographic coupling.

Analisis sitasi muncul dari asumsi melalui sitasi kita dapat mengetahui hubungan antar artikel, sejarah perkembangan ide dan penemuan topik riset tertentu, dan kolaborasi antar penulis. Selain itu juga terkait dengan upaya untuk melakukan validasi dan menguji hukum-hukum statistik dalam studi bibliografi misalnya membuktikan kebenaran hukum Lotka terkait paruh hidup literatur. Motif ketiga yang saat sekarang yang paling banyak digunakan adalah untuk melakukan asesmen, evaluasi, dan pemeringkatan. Motif ketiga ini berkembang luas dan banyak menimbulkan kontroversi karena dihubungkan dengan penilaian promosi dan jabatan. Bahkan di beberapa negara digunakan sebagai indikator kualitas untuk memberikan penghargaan dan pendanaan riset (White, 2004).

\subsection{Evaluasi kinerja riset}

Evaluasi kinerja riset berawal dari konsep ekonomi dan dipengaruhi oleh disiplin ilmu yang mengkajinya seperti ilmu ekonomi, sosiologi, filosofi, dan informasi. Setiap disiplin ilmu memiliki pandangan yang berbeda terutama terhadap indikator dan variabel dalam pengukuran kinerja. Penulis belum menemukan adanya kerangka teori yang menjelaskan penggunaan masing-masing kategori metrik ini secara tepat. Literatur yang sudah ada lebih banyak membahas pengukuran kinerja riset terkait aplikasi praktisnya. Pondasi teori sebagai latar belakang dari pengukuran kinerja riset masih sangat kurang. Termasuk teori dalam 
penentuan indikator pengukuran baik untuk skala mikro maupun makro. Hal ini terlihat ketika indikator dalam pengukuran kinerja memang lebih banyak ditentukan berdasarkan pengalaman (posteriori)(Geisler, 2005).

Sejak berkembangnya kajian kuantitatif sains, terjadi pergeseran paradigma dari evaluasi oleh expert (peer review) ke evaluasi berbasis bibliometrik dan saintometrik (Belter, 2015). Menurut (Molas-Gallart \& Ràfols, 2018) ada tiga hal yang menyebabkan perubahan ini. Pertama adanya kebutuhan terhadap evaluasi riset yang tidak dapat sepenuhnya mengandalkan pada proses peer review. Kedua, evaluasi menggunakan bibliometrik dianggap lebih obyektif daripada peer review yang bersifat subyektif. Ketiga indikator bibliometrik dapat diakses dengan mudah oleh semua pihak termasuk praktisi seperti manajer dan politisi. Penggunaanya pun terlihat lebih sederhana dan langsung pada pengambilan keputusan. Ketika negara berkembang menggunakan indikator ini dianggap memiliki legitimasi internasional dibandingkan menggunakan pakar mereka yang dianggap tingkat lokal. Selain itu, pertumbuhan jumlah publikasi yang sangat besar membuat kajian kuantitatif lebih bisa mencakup data yang lebih luas dan lebih cepat. Seyogyanya, kedua pendekatan ini saling melengkapi sehingga kualitas evaluasi menjadi lebih baik.

\section{METODE PENELITIAN \\ 1. Kerangka metodologi}

Kajian ini mengadopsi kerangka metodologi teori kritis kontemporer (Strydom, 2011). Strydom membagi metodologi dalam teori kritis dalam tiga tahap yaitu (1) pernyataan masalah, (2) diagnosa dan eksplanasi kritik, dan (3) validasi ilmiah dan publik, serta aplikasi praktis. Ketiga tahap ini dapat diulang untuk perbaikan hasil. Masalah dalam teori kritis dapat dimulai dari masalah dan kondisi obyek yang tertindas, menderita atau dalam permasalahan tertentu. Selanjutnya digunakan logika dan imaginasi untuk menghubungkan masalah dengan kemungkinan diagnosa dan solusi secara teori. Tahapan diagnosa berisi kegiatan mengidentifikasi problem, merekonstruksi sejarah elemen-elemen yang mempengaruhi kondisi saat ini, dan mengeksplanasi kritik baik positif maupun negatif terhadap kondisi yang ada. Diagnosa dilengkapi dengan mencari subtansi teori yang berkaitan dengan masalah. Pada tahap terakhir dilakukan validasi dengan menggunakan teori ilmiah yang ada, konfimasi antar subyek, dan perumusan langkah praktis dan pragmatis untuk memberikan penyelesaian masalah dan perubahan baru. Kerangka tahapan metode disajikan dalam Gambar 3. Tidak semua tahapan menurut Strydom (2011) diadopsi dan menjadi kekurangan kajian ini yaitu tidak dilakukan validasi antar subyek. Rekomendasi pemecahan masalah bersifat teoritis dan berdasarkan pada perspektifilmu komputer.

\section{Pengumpulan dan analisis data}

Data yang digunakan terdiri atas tiga kategori yaitu (1) konten literatur yang digunakan untuk telaah kritis, (2) data publikasi kajian kuantitatif sains di tingkat nasional dan global sebagai data pendukung, serta (3) hasil pengamatan dan pengalaman penulis sebagai peneliti yang beberapa kali melakukan kajian kuantitatif sains dan terlibat dalam perumusan konsep dan metode evaluasi kinerja riset. Sumber data literatur yakni basis data Google scholar, Microsoft academic search, dan Garuda Ristekdikti tanpa batasan tahun. Literatur yang ditelaah adalah mengenai analisis sitasi, kajian sains dan teknologi, pengukuran kinerja riset, dan teori kritis. Konten dalam literatur ditelaah secara kritis untuk menjawab pertanyaan penelitian dengan penekanan pada aspek sejarah, sosial, dan teknis. Pemahaman terhadap kondisi riset bidang kajian kuantitatif sains dilakukan melalui analisis publikasi baik pengukuran kuantitatif metadata maupun analisis konten. Adapun hasil pengamatan dan pengalaman penulis digunakan sebagai sudut pandang dan memperkaya proses penelaahan. Selanjutnya hasil penelaahan kritik digunakan untuk merumuskan rekomendasi solusi, dan tindak lanjut perubahan yang tepat. Kajian ini membatasi penyusunan solusi berbasis pada kajian literatur teori dan empiris dari perspektif ilmu komputer. 


\section{HASILDAN PEMBAHASAN}

1. Kritik sitasi dalam publikasi ilmiah

Hasil analisis publikasi pada basis data Google scholar dan Microsoft academic search menunjukkan jumlah publikasi yang membahas dan menggunakan analisis sitasi tumbuh sangat pesat (Gambar 4). Di tingkat internasional, publikasi topik ini mulai muncul sejak tahun 1962 dan sampai tahun 2018 total publikasi adalah 9.367 dokumen. Jumlah publikasi terbanyak terjadi pada tahun 2012 sebanyak 726 publikasi. Pada tahun-tahun berikutnya jumlah publikasi tetap tinggi yaitu rata-rata 552 dokumen per tahun.

Analisis terhadap konten publikasi analisis sitasi, sangat sedikit yang membahas kelemahan atau kritik terhadap metode ini. Jumlah dokumen yang melakukan telaah kritis terhadap analisis sitasi hanya ditemukan sebanyak 32 dokumen $(0,3 \%)$. Adapun sub topik yang banyak dibahas adalah eksperimen menggunakan metode bibliometrik dan saintometrik, serta beberapa metrik utama seperti impact factor. Terlihat bahwa metode analisis sitasi termasuk teknik turunanya diterima secara luas dan digunakan oleh peneliti dengan sangat sedikit sekali telaah kritis untuk memperbaiki metode ini. Hal ini menguatkan anggapan pandangan positivisme, dimana metode analisis sitasi sebagian besar menerapkan paradigma positivisme, bahwa "propaganda" mengenai metode kuantitatif obyektif yang diklaim netral berhasil menyebabkannya mudah diterima oleh komunitas (Kodir, 2016).

Kondisi seperti ini juga sama dengan penelitian analisis sitasi di Indonesia. Analisis terhadap publikasi Indonesia di Google scholar dan Garuda Ristekdikti menunjukkan jumlah publikasi analisis sitasi di Indonesia berjumlah 142 dokumen. Dari jumlah tersebut, hanya ditemukan dua dokumen yang mengkritisi metode ini yaitu terkait teknis kesalahan dalam penulisan sitasi di bibliografi dan etis dalam kartelisasi sitasi di Indonesia. Sebagian besar publikasi analisis sitasi di Indonesia adalah eksperimen menggunakan metode yang ada untuk mengkaji data di Indonesia. Belum ada kajian yang membahas secara khusus berupa kritik atau perbaikan terhadap konsep maupun metode dalam analisis sitasi. Kritik terhadap implementasi dan etika banyak di media sosial dan diskusi-diskusi, namun tidak banyak dituangkan secara ilmiah dalam publikasi. Adapun kebaruan dalam riset analisis sitasi di Indonesia bersifat studi kasus dan rekomendasi terhadap metrik (contohnya rumus sinta score). Namun tidak pada pondasi dasar konsep maupun indikator baru yang berbeda dengan yang sudah ada.

Data publikasi di atas memberikan gambaran bahwa telaah kritik dalam riset analisis sitasi belum menjadi budaya. Di Indonesia, peneliti topik ini mudah menerima konsep dan metode yang sudah mapan dan berasal dari negara yang lebih maju. Kritik yang ada jumlahnya sedikit dan belum menyasar terhadap perkembangan konsep dan metodologi dalam analisis sitasi. Hal ini menjadi sangat ironis, karena jumlah publikasi yang menggunakan analisis sitasi tumbuh sangat besar, tanpa diimbangi dengan upaya untuk terus memperbaiki metode yang umum dipakai.

\section{Telaah kritis terhadap konsep, metode, dan implementasi analisis sitasi}

Hasil telaah kritis terhadap analisis sitasi secara keseluruhan dipetakan dalam Gambar 5. Peta ini memberikan gambaran permasalahan sitasi bersifat menyeluruh dari konsep, metode, dan implementasi. Kekurangan dimulai dari paradigma positivisme yang gagal mencapai tujuannya untuk menjamin obyektivitas dan bebas nilai dalam pencarian kebenaran. Adapun dari sisi metode, kritik ditekankan pada banyaknya bias mulai dari sumber data, teknis pengumpulan data, metode analisis yang hanya menggunakan metadata, dan interpretasi hasil yang sangat tergantung pada kemampuan teknis peneliti yang pada beberapa kondisi masih rendah. Kritik yang ketiga terletak pada isu bias ideologi dan etika dalam implementasi khususnya penggunaan analisis sitasi untuk evaluasi kinerja riset. Ideologi yang berperan besar adalah kapitalisme yang menyebabkan peneliti dan pemerintah di negara berkembang semakin tertindas oleh dominasi barat. Adapun isu etika terkait dengan adanya kasus peneliti 
yang melakukan tindakan tidak etis seperti kartel sitasi dan lembaga yang lebih berorientasi pada prestise dibandingkan kualitas riset ilmiah. Berikut penjelasan setiap kritik.

\subsection{Kritik terhadap paradigma positivisme dalam analisis sitasi}

Analisis sitasi menggunakan paradigma positivisme sebagai kerangka metodologi penelitiannya. Garfield (1983) yang menjadi pionir dalam analisis sitasi secara jelas menggunakan asumsi-asumsi positivisme dalam membangun konsepnya. Salah satunya bahwa analisis ini harus independen obyektif mengikuti norma sains yang dikemukan oleh Merton bahwa ras, kebangsaan, agama, kelas dan kualitas personal tidak ada relevansinya dengan perkembangan sains (Sinay, Sinay, Carter, \& Martins, 2019).

Positivisme muncul sebagai jawaban alternatif atas dianggap gagalnya filsafat spekulatif Kant dan Hegel. Reaksi epistemologi ini menolak kebenaran berbasis metode spekulatif yang ternyata jauh dari kebenaran. Gagasan utama positivisme adalah filsafat harus ilmiah bukan spekulatif dan ilmu pengetahuan harus memenuhi kriteria yaitu bebas nilai, metode verifikasi empiris, nominalis, naturalis, dan mekanis. Dalam perkembangannya, positivisme banyak mengalami perubahan yang ternyata justru menjauh dari tujuan awal yang ditawarkan dalam mencari kebenaran (Wuryanta, 2018).

Perbedaan tujuan dan hasil dari positivisme ini dapat dipelajari dalam metode indeksasi jurnal yang menggunakan analisis sitasi. Metode indeksasi yang berusaha menghindari bias ternyata justru menyebabkan bias besar dalam perkembangan ilmu pengetahuan. Obyektivitas dalam metode indeksasi justru semakin mengokohkan hegemoni sains yang berasal dari perspektif hasil riset kelompok tertentu yaitu laki-laki dari negara maju dan berbahasa Inggris. Padahal supaya tidak bias, sains seharusnya dibangun dari berbagai perspektif bukan hanya dari perspektif dari kelompok yang sejenis. Hal ini supaya perkembangan sains tidak bias dan sadar bias.
Selain kritik terhadap positivisme, penggunaan metode kuantitatif untuk menilai aspek kualitatif dalam analisis sitasi untuk evaluasi riset juga menjadi pertanyaan. Sampai sekarang belum dapat diuji secara pasti bagaimana hubungan antara kuantitas sitasi dengan kualitas publikasi dan riset. Sitasi dihitung secara kuantitatif dan dianggap sebagai proxi terhadap dampak dan kualitas riset. Hal ini merupakan asumsi dari hubungan linear sederhana antara jumlah sitasi dan kualitas riset. Namun pola sitasi sangat bervariasi, bersifat komplek, sehingga tidak semudah itu menghubungkan kuantitas sitasi dengan kualitas riset. Misalnya sitasi dalam satu bidang yang mendapat perhatian luas akan sangat tinggi dibandingkan bidang lain yang peminatnya sedikti, sehingga bukan berarti kualitas artikel dibidang ini menjadi lebih rendah (Wallin, 2005).

\subsection{Kritik terhadap metode analisis sitasi: sumber data, unit analisis, dan skala analisis}

Kelemahan pertama dari metode analisis sitasi adalah terkait basis data yang menjadi sumber pengumpulan data sitasi. Masalahnya terletak pada desain basis data adalah untuk temu kembali informasi. Penggunaan untuk kajian sains bukanlah tujuan utama sehingga desain basis data sering tidak sepenuhnya mendukung metode seperti bibliometrik. Beberapa masalah akan muncul dalam pengumpulan data antara lain data yang salah (penulisan) atau tidak konsisten (contohnya penamaan subyek), cakupan data, tumpang tindih, berubah-ubah misalnya karena jeda dalam pemutakhiran konten basis data dibanding tanggal terbit, serta perubahan kebijakan atau praktis basis data, serta keterbatasan sarana untuk analisis (Hood \& Wilson, 2003).

Kondisi tersebut menyebabkan peneliti harus melakukan pengolahan data terlebih dahulu (pre-processing) dengan baik untuk menghasilkan riset yang benar. Salah satunya dengan melakukan normalisasi misalnya terkait penulis banyak, tipe dokumen dan disiplin ilmu (Wallin, 2005). Kondisinya di lapangan, banyak 
peneliti yang tidak cukup memiliki kemampuan ini sehingga data langsung dianalisis tanpa pengolahan terlebih dahulu. Akibatnya hasil analisis menjadi tidak tepat. Khusus untuk database sitasi seperti Scopus, masalah terutama pada cakupan dimana hanya sedikit sekali jurnal yang diindeks sehingga menjadi bias terutama untuk kajian di negara berkembang dimana artikel yang didindeks jauh lebih sedikit (kecil sekali persentasenya) dibandingkan total publikasi negara tersebut.

Hal ini sering terjadi dalam analisis untuk melihat pola publikasi. Kajian seperti ini seharusnya menggunakan jumlah total publikasi dari laporan tahunan suatu lembaga, sedangkan banyak terjadi hanya menggunakan sumber dari basis data sehingga banyak data publikasi yang kurang (publication loss). Kondisi ini tidak hanya untuk negara berkembang yang publikasi terindeks internasionalnya sedikit. Bagi negara maju juga masih ada publication loss tergantung bidang ilmu yang bisa mencapai angka 50\%. Publication loss bidang ilmu kesehatan ditemukan paling besar dibandingkan bidang lain (Wallin, 2005).

Kritik kedua dalam metode analisis sitasi saat ini semua metrik menghitung sitasi secara sederhana dari bagian daftar pustaka. Metode ini memiliki beberapa kelemahan antara lain semua sitasi dihitung termasuk sitasi negatif. Dengan teknik ini artikel yang dikutip karena dianggap kurang berkualitas justru dihitung sebagai sitiran berkualitas. Selain itu teknik ini juga menghitung sitasi sendiri (self-citation)(White, 2004). Penulisan sitasi dalam daftar pustaka juga masih banyak yang salah, seperti perbedaan antara jumlah sitasi dalam teks dengan di referensi dan juga kesalahan pengetikan. Di publikasi internasional, terdapat sekitar $18.75 \%$ sitasi yang ditulis di bagian referensi ternyata tidak digunakan dalam teks utuhnya (Shahid, Afzal, \& Qadir, 2015). Penulis belum menemukan data ini di publikasi Indonesia. Namun diperkirakan jumlahnya lebih besar dibandingkan data di publikasi internasional karena masih banyak penulis yang belum menggunakan aplikasi pengelolaan referensi. Penulisan secara manual berpotensi terjadi tidak konsisten antara sitasi di teks dan di daftar pustaka. Hal ini terutama di jurnal yang belum terakreditasi.

\subsection{Permasalahan impementasi analisis sitasi untuk evaluasi kinerja riset}

Permasalahan dalam tahap implementasi dapat disebabkan oleh faktor subyek peneliti seperti kesalahan menerapkan konsep, kesalahan interpretasi, dan perubahan level evaluasi. Analisis sitasi dapat digunakan sebagai pendamping yang berharga untuk melengkapi proses peer review, namun seringkali penggunaanya keluar dari kontek dan diaplikasikan tanpa sepenuhnya memahami dasar penghitungan matematikanya. Akibatnya, peneliti sering mengukur sesuatu yang tidak pas unutk diukur dan membuat perbandingan yang sebenarnya tidak mampu dibuat (Belter, 2015).

Evaluasi kinerja dapat dilakukan dalam beberapa level antara lain level individu, artikel, jurnal, organisasi, negara, dan skala internasional. Tradisional metrik untuk ranking seharusnya tidak tepat digunakan untuk level individu, karena area indikator yang tidak sensitif terkait kecilnya sampel. Namun saat ini masih banyak ditemukan penggunaan metrik ranking secara tidak tepat (Andersen, 2017). Permasalahan ini dapat menyebabkan analisis dalam skala mikro sampai makro menjadi tidak jelas dan tidak dapat sepenuhnya memberikan hasil yang terbaik (MacRoberts \& MacRoberts, 1989). Sitasi sebagai parameter utama dalam kajian bibliometrik, bersifat tidak stabil karena tidak sama antar disiplin, bahasa, dan jenis riset. Oleh karena itu, sitasi yang diperlakukan secara sama sebagai indikator kualitas riset pada semua level menjadi diragukan (Molas-Gallart \& Ràfols, 2018)

\subsection{Isu etika dan bias ideologi dalam analisis sitasi}

Sitasi selama beberapa dekade dijadikan indikator pemeringkatan dan penghargaan akademis. Salah satu kelemahan adanya keuntungan kumulatif bagi penulis yang sudah banyak disitasi untuk mendapatkan lebih banyak sitasi (Leydesdorff \& Milojevic, 2015). Hal ini terkait dengan kecenderungan penulis untuk mengutip artikel yang sudah banyak 
dikutip dibandingkan artikel lain yang sejenis atau bahkan seharusnya lebih layak dikutip. Kelemahan lain dari indikator sitasi ini adanya bias untuk penilaian kajian interdisplin, mendorong perubahan motivasi dari riset individu dan lembaga, lebih menyebabkan adanya hirarki prestise lembaga daripada mendorong kompetisi dan kolaborasi antara lembaga (Jappe, Pithan, \& Heinze, 2018). Masalah etika juga muncul dari adanya kasuskasus manipulasi oleh peneliti untuk menaikan nilai/ranking mereka (Wilkinson, 2018).

Di Indonesia, salah satu isu etika yang menarik yakni dugaan adanya kartel sitasi yang muncul setelah adanya sistem sinta sebagai pendukung evaluasi kinerja riset oleh pemerintah. Kartelisasi berasal dari istilah ekonomi yang merujuk pada adanya perjanjian yang mengakibatkan adanya praktek monopoli atau persaingan usaha yang tidak sehat. Istilah kartel sitasi mengarah pada upaya-upaya yang dilakukan untuk meningkatkan jumlah sitasi secara tidak etis (Ronda, 2019). Data yang diungkap oleh Kementerian Ristekdikti dan berita di media massa, tindakan ini meliputi sitasi sendiri (self-citation) dalam jumlah yang tidak wajar (berlebihan) padahal tidak relevan. Selain itu juga tindakan tidak etis dimana ditemukan kasus dosen yang mewajibkan mahasiswa mengutip tulisan dosen dalam penulisan tugas akhir. Pengalaman penulis juga menemukan beberapa jurnal yang mewajibkan penulis yang mengajukan (submit) artikel untuk diterbitkan wajib mengutip minimal 2-3 artikel yang sudah terbit dalam jurnal tersebut. Hal ini bertujuan supaya jumlah sitasi dan peringkat jurnal meningkat. Praktik seperti ini melanggar etika publikasi ilmiah, karena adanya kewajiban menyebabkan kutipan tidak relevan dan tidak bermakna.

Selain memiliki bias dan isu etika, kritik lain adanya ideologi kapitalisme dalam implementasi analisis sitasi. Jika melihat dari besarnya keuntungan dari bisnis penerbit jurnal dan indeksasi, ada kemungkinan memang sitasi dalam indeksasi telah menjadi ladang bisnis rumah perhitungan (the counting house). Selain itu dari sejarah dapat memperlihatkan nilai apa dibalik indeksasi. Garfield pada awalnya membangun perusahaan bernama Eugene Garfield Associates Inc. pada tahun 1955 kemudian berubah menjadi Institute for Scientific Information (ISI) pada tahun 1960. ISI ini yang kemudian memperkenalkan WOS. Perubahan nama menjadi ISI diduga sebagai salah satu cara supaya terdengar sebagai lembaga non-profit dan tidak berbau komersil. Bahkan sampai saat ini masih banyak yang menganggap ISI merupakan lembaga non-profit dan percaya bahwa WOS benar-benar bebas dari misi meraih untung. Padahal dari awal WOS, pengindeks jurnal yang pertama, yakni produk bisnis komersial (Kinouchi, 2014), dan saat ini, hampir sebagian besar pengindeks merupakan perusahaan bisnis dengan omset besar.

Impact factor yang merupakan metrik pertama yang mengenalkan analisis sitasi dianggap sebagai merek dagang (brand) yang didesain supaya laku untuk dijual. Kenapa disebut impact factor? Kenapa bukan disebut rata-rata sitasi dalam dua tahun? Padahal impact factor adalah rumus menghitung jumlah sitasi yang diperoleh suatu jurnal setelah dua tahun terbit. Dari bahasa impact factor, seolah-olah jumlah sitasi ini menjadi faktor utama sesuatu menjadi berdampak. Bukankah ini semacam strategi bahwa kalau memasukkan jurnal untuk diterbitkan di jurnal dengan impact factor tinggi akan banyak disitir? Padahal kenyataannya tidak ada korelasi yang kuat bahwa artikel di jurnal dengan impact factor tinggi akan disitasi oleh banyak orang (Finardi, 2013).

\section{Solusi permasalahan dan rekomendasi tindak lanjut}

Telaah literatur dan pengamatan dalam analisis sitasi menunjukkan banyak kekurangan dalam konsep dan metode analisis sitasi yang saat ini dipakai luas. Walaupun mendapatkan banyak kritik, paradigma analisis sitasi terus dipakai. Pergeseran ke arah perbaikan paradigma baru sangat lambat. Dari awal, munculnya kritik memicu adanya kelompok yang protagonis dan antagonis. Namun antara mereka terlihat tidak ada komunikasi, sehingga tidak memberikan perbaikan terhadap perkembangan metode ini sendiri. Para pendukung paradigma analisis sitasi yang ada, 
menganggap masalah (anomali) yang muncul hanya memiliki dampak yang sangat kecil, hanya semacam kebisingan acak terhadap paradigma yang semakin membesar. Anomali ini dikritik secara berulang namun juga lemah, terdistorsi, terpecah-pecah dan tidak koheren (MacRoberts \& MacRoberts, 1989).

Dari sisi sosiologi, Jappe dkk menyelidiki kenapa ini terjadi menggunakan teori profesi Andre Abbott dan teori kerja ilmiah oleh Richard whitley. Kajian menghasilkan temuan bahwa konsep analisis sitasi tidak dapat menjadi otoritas untuk melakukan asesmen riset profesional terkait dengan teori organisasi. Namun, adanya kebutuhan yang tinggi untuk melakukan evaluasi kinerja riset dan terbatasnya pakar yang mampu melakukan asesmen menyebabkan penyedia database dan metrik menjadi pilihan yang banyak digunakan walaupun tahu bahwa metode tersebut memiliki banyak kekurangan (Jappe et al., 2018).

Dari perspektif ilmu komputer permasalahan yang dapat diatasi adalah terkait banyaknya kritik dari metode analisis sitasi bila menghitung secara sederhana dari referensi. Solusi yang diusulkan yakni perubahan ke arah analisis sitasi dalam teks untuk melihat konten dan konteks bahasanya. Ada empat tujuan dalam analisis ini yaitu: (1) apakah sitasi bersifat konseptual atau teknis (mengutip konsep/teori atau teknik/metode), (2) apakah menunjukkan evolusi sains atau sejajar (referensi sebagai pondasi riset atau alternatif dari referensi sebelumnya), (3) apakah sitasinya kuat (organic) atau sekedarnya (perfunctory), dan (4) apakah sitasinya berfungsi positif atau negatif. Keempat parameter ini bertujuan untuk menjawab kata dampak yang dikaitkan dengan sitasi dari benar-benar menganalisis nilai dan manfaat sitasi (White, 2004).

Konsep analisis sitasi dalam teks dapat membedakan makna dalam sitasi. Berdasarkan lokasi sitasi dalam teks, analisis ini membagi artikel yang dikutip menjadi sitasi esensial dan periferal. Kutipan esensial dilihat dari makna dan intensitas yang tinggi, sedangkan periferal dilihat dari kurangnya makna atau intensitas yang rendah. Analisis yang dilakukan oleh Maricic, Spaventi, Pavicic, \& Pifat-mrzljak
(1998) menghasilkan temuan bahwa kutipan periferal yang dominan ada dalam pendahuluan. Sedangkan, kutipan esensial yang dominan terjadi pada kutipan dalam metodologi, hasil, dan sesi diskusi. Temuan ini diperkuat oleh Athar \& Teufel (2012) bahwa kutipan di bagian metodologi lebih relevan daripada di bagian tinjauan literatur. Demikian juga, artikel yang dikutip dalam bab pendahuluan dianggap sebagai artikel pendukung, sedangkan artikel yang dikutip dalam bab hasil dianggap sebagai kutipan utama. Relevansi hubungan antara artikel yang dikutip dan artikel yang dikutip juga dapat dilihat berdasarkan lokasi dalam kutipan dalam teks.

Selain lokasi, analisis konteks sitasi dapat memberikan informasi mengenai sentimen dan tujuan penulis dalam mengutip. Sentimen sitasi dapat dibagi dalam tiga jenis yaitu positif ketika sitasi menkonfirmasi artikel yang disitir, negatif bila sitasi memberikan kritik atau menolak artikal yang dikutip, dan netral bila tidak ada sentimen yang muncul (Yousif, Niu, Tarus, \& Ahmad, 2017). Analis teks juga dapat membedakan fungsi dari sitasi. Tujuan sitasi sangat beragam namun secara garis besar dapat dibagi menjadi enam yaitu mengkritisi, membandingkan, menggunakan, menjadi substansi, menjadi dasar, netral atau tujuan lainnya (Abu-jbara, Ezra, \& Radev, 2013). Usulan variabel dalam analisis sitasi dalam teks ditampilkan dalam Gambar 6.

Analisis terhadap konteks sitasi jika dilakukan secara anotasi manual akan sangat tidak efektif dan efisien mengingat jumlah dokumen publikasi saat ini sangat banyak. Pendekatan pemelajaran mesin dapat digunakan untuk analisis ini. Kajian yang sudah dilakukan peneliti bidang ilmu komputer menunjukkan potensi keberhasilan yang tinggi. Beberapa hasil penelitian sudah bisa mengklasifikasi apakah sitasi positif atau negatif dengan menggunakan metode support vector machine (SVM), convolutional neural network $(\mathrm{CNN})$, dan bidirectional long short-term memory (BiLSTM). Akurasi metode ini mencapai angka di atas 80\% (Elabdi, Smine, \& Ben Yahia, 2018; Kilicoglu et al., 2019; Ikram \& Afzal, 2019). Peneliti lain juga sudah melakukan klasifikasi 
dengan menggabungkan variabel lain yaitu intensitas dan tujuan sitasi. Hasilnya diperoleh kelas sitasi penting dan tidak penting. Penelitian ini menggunakan teknis multitask learning dan hybrid features. Akurasi hasilnya cukup tinggi antara 88-93\%. (Hussain et al., 2019; Yousif, Niu, Chambua, \& Khan, 2019). Kekurangan penelitian-penelitian ini umumnya pada jumlah dataset yang masih sedikit dan berasal dari satu bidang ilmu. Selain itu, variabel yang dianalisis belum mencakup semua konsep yang diusulkan sebagai dasar sitasi yang berkualitas. Usulan perubahan metode ini membutuhkan penelitian lebih lanjut dengan menggunakan data yang lebih banyak, dari berbagai disiplin ilmu dan juga publikasi berbahasa Indonesia. Tantangan riset ini yang perlu dijawab oleh peneliti bidang ilmu komputer.

\section{E. KESIMPULAN}

Analisis sitasi mendapatkan banyak kritik terutama bagian metode/teknis analisis. Masalah berpusat pada pengukuran secara sederhana dari sitasi di bagian referensi. Hasil pengukuran ini menjadi tidak valid dan membutuhkan solusi berupa perubahan konsep dari unit dan teknik analisis. Perspektif ilmu komputer menawarkan metode analisis sitasi dalam teks lengkap menggunakan teknologi pemelajaran mesin khususnya deep learning. Perubahan konsep ini diharapkan dapat mengatasi masalah dalam analisis sitasi seperti tidak jelasnya definisi dampak dan manfaat serta beberapa bias yang sebelumnya ada. Analisis sitasi memerlukan perbaikan dari berbagai aspek, tidak hanya metode. Makalah ini membatasi solusi dan rekomendasi tindak lanjut berbasis perspektif ilmu komputer sehingga hanya cocok untuk perbaikan yang bersifat teknis analitik. Perbaikan aspek lain memerlukan perspektif dari bidang ilmu lain yang terkait seperti filsafat ilmu, sosiologi, dan ilmu informasi. Perspektif ilmu-ilmu ini justru lebih kuat aspek konteks Indonesia sehingga sangat penting untuk dibangun. Kajian selanjutnya perlu melibatkan bidang ilmu lain seperti filsafat, sosiologi, ilmu perpustakaan dan informasi, serta manajemen dan kebijakan iptek untuk merumuskan berbagai pondasi yang diperlukan khususnya bila metode analisis berbasis teks dan konteks akan diterapkan sebagai instrumen dalam evaluasi kinerja riset.

\section{DAFTAR PUSTAKA}

Abu-jbara, A., Ezra, J., \& Radev, D. (2013). Purpose and polarity of citation : Towards NLP-based Bibliometrics. Proceedings OfNAACL-HLT, (June), 596-606. Atlanta, Georgia: Association for Computational Linguistics.

Andersen, J. P. (2017). An empirical and theoretical critique of the Euclidean index. Journal of Informetrics, 11(2), 455-465. https://doi.org/10.1016/j.joi.2017.02.009

Athar, A., \& Teufel, S. (2012). ContextEnhanced Citation Sentiment Detection. Conference Ofthe North American Chapter Ofthe Association for Computational Linguistics: Human Language Technologies, 597-601. Montr'eal, Canada.

Belter, C. W. (2015). Bibliometric indicators: Opportunities and limits. Journal of the Medical Library Association, 103(4), 219-221. https://doi.org/10.3163/15365050.103.4.014

Bernstein, R. (1991). Habermas and Modernity (R. Bernstein, ed.). Cambridge, Massachusetts: The MIT Press.

Buranyi, S., \& McKenzie, D. (2017). Is the staggeringly profitable business of scientific publishing bad for science? https://doi.org/10.1371/journal.pmed.0050 201

Cobo, M. J., Lopez-Herrera, A. G., HerreraViedma, E., \& Herrera, F. (2011). Science mapping software tools : review, analysis, and cooperative study among tools. Journal of American Society for Information Science and Technology, 62(7), 1382-1402. https://doi.org/10.1002/asi

De Bellis, N. (2010). Bibliometrics and Citation Analysis: From the Science Citation Index to Cybermetrics (Vol. 23). https://doi.org/10.1087/20100312 
Elabdi, M., Smine, B., \& Ben Yahia, S. (2018). DFBICA: A new distributed approach for sentiment analysis of bibliographic citations. Proceedings - International Conference on Research Challenges in Information Science, 2018-May, 1-6. https://doi.org/10.1109/RCIS.2018.840667 2

Finardi, U. (2013). Correlation between Journal Impact Factor and Citation Performance: An experimental study. Journal of Informetrics, 7(2), 357-370. https://doi.org/10.1016/j.joi.2012.12.004

Garfield, E. (1983). Citation Indexing, Its Theory and Application in Science, Technology, and Humanities. Philadelphia: ISI Press.

Geisler, E. (2005). The measurement of scientific activity : Research directions in linking philosophy of science and metrics of sciences and technology outputs. Scientometrics, 62(2), 269-284.

Hood, W., \& Wilson, C. (2003). Hood, Wilson 2003 - Informetric studies using databases Opportunities and challenges.pdf. Scientometrics, 58(3), 587-608.

Hussain, S. J., Maqsood, S., Jhanjhi, N., Khan, A., Supramaniam, M., \& Ahmed, U. (2019). A Comprehensive Evaluation of CueWords based Features and In-text Citations based Features for Citation Classification. International Journal of Advanced Computer Science and Applications, 10(7), 209-218. https://doi.org/10.14569/ijacsa. 2019.0100730

Ikram, M. T., \& Afzal, M. T. (2019). Aspect based citation sentiment analysis using linguistic patterns for better comprehension of scientific knowledge. Scientometrics, 119(1), 73-95. https://doi.org/10.1007/ s11192-019-03028-9

Iwan, I. (2014). Menelaah Teori Kritis Jurgen Habermas. Jurnal Edoeksos, III(2), $145-165$.

Jappe, A., Pithan, D., \& Heinze, T. (2018). Does bibliometric research confer legitimacy to research assessment practice? A sociological study of reputational control, 1972-2016. PLoS ONE, 13(6), 1-28. https://doi.org/10.1371/journal.pone.0199 031

Kilicoglu, H., Peng, Z., Tafreshi, S., Tran, T., Rosemblat, G., \& Schneider, J. (2019). Confirm or refute?: A comparative study on citation sentiment classification in clinical research publications. Journal of Biomedical Informatics, 91(January), 103123. https://doi.org/10.1016/j.jbi.2019. 103123

Kinouchi, R. R. (2014). Scientometrics : the project for a science of science transformed into an industry of measurements. Scientiae Studia, 12, 147-159.

Kodir, A. (2016). Corporate Social Responsibility ( Csr ), Ideologi Dan Keberpihakan Di Indonesia : Telaah Teori Kritis Madzhab Frankfurt Corporate Social Responsibility, Ideology And Aligment In Indonesia : Study Of Frankfurt School Critical Theory. Jurnal Sosiologi Pendidikan Humanis, 1(2), 149-160.

Leydesdorff, L., \& Milojevic, S. (2015). Scientometrics. In M. Lynch (Ed.), International Encyclopedia of Social and Behavioral Sciences (2nd Editio, pp. 322-327). Oxford: Elsevier.

MacRoberts, M. H., \& MacRoberts, B. R. (1989). Problems of citation analysis: A critical review. Journal of the American Society for Information Science, 40(5), 342-349. https://doi.org/10.1002/ (SICI)1097-4571(198909)40:5<342::AIDASI7>3.0.CO;2-U

Magnis-Suseno, F. (1992). Filsafat Sebagai Ilmu Kritis. Yogyakarta: Kanisius.

Maricic, S., Spaventi, J., Pavicic, L., \& Pifatmrzljak, G. (1998). Citation Context versus the Frequency Counts of Citation History. Journal of American Society for Information Science, 49(6), 530-540. https://doi.org/https://doi.org/10.1002/(SI CI)1097-4571(19980501)49:6<530::AIDASI5>3.0.CO;2-8

Merton, R. (1942). Science and Technology in a Democratic Order. Journal of Legal and Political Sociology, (1), 115-126. 
Molas-Gallart, J., \& Ràfols, I. (2018). Why bibliometric indicators break down: Unstable parameters, incorrect models and irrelevant properties. BiD, 40(40). https://doi.org/10.1344/BiD2018.40.23

Ronda, D. (2019). Kartelisasi Sitasi Ditinjau Dari Perspektif Kristen. Integritas: Journal Teologi, 1(1), 29-37.

Sengupta, I. (1992). Bibliometrics, Informetrics, Scientometrics and Librametrics: An Overview. Libri: International Library Review, 42(2), 75-98. https://doi.org/10.1515/libr. 1992.42.2.75

Shahid, A., Afzal, M. T., \& Qadir, M. A. (2015). Lessons learned: The complexity of accurate identification of in-text citations. International Arab Journal of Information Technology, 12(5), 481-488.

Sinay, L., Sinay, C., Carter, B., \& Martins, A. (2019). Reflections about Garfield's Algorithm. RAUSP Management Journa, 2531-0488. https://doi.org/10.1108/ RAUSP-05-2019-0079

Strydom, P. (2011). Contemporary Critical Theory and Methodology. New York: Routledge Taylor \& Francis Group.

Tennant, J. (2018). Elsevier are corrupting open science in Europe. Retrieved November 12, 2019, from The Guardian website: https://www.theguardian.com/science/poli tical-science/2018/jun/29/elsevier-arecorrupting-open-science-in-europe

Vosloo, J. (2011). Chapter 5: Research design and methodology.

Wallin, J. A. (2005). Bibliometric methods: Pitfalls and possibilities. Basic and Clinical Pharmacology and Toxicology, 97(5), 261-275. https://doi.org/10.1111/j.17427843.2005.pto_139.x
White, H. D. (2004). Citation Analysis and Discourse Analysis Revisited. Applied Linguistics, 25(1), 89-116+132. https://doi.org/10.1093/applin/25.1.89

Wilkinson, J. (2018). Bibliometrics and Research Evaluation: Uses and Abuses,. Journal of Web Librarianship, 12(1), 80-80. https://doi.org/10.1080/ 19322909.2018.1408448

Wisri, W., \& Mughni, A. (2016). Paradigma dasar fenomenologis, hermeneutika dan teori kritis. Jurnal Lisan Al-Hal, 10(1), 5-21.

Wuryanta, E. (2018). Teori Kritis dan Varian Paradigmatis dalam Ilmu Komunikasi. https://doi.org/https://doi.org/10.31227/osf .io/wk4p9

Wyatt, S., Milojević, S., Park, H. W., \& Leydesdorff, L. (2015). Quantitative and Qualitative STS : The intellectual and practical contributions of scientometrics. Retrieved from SSRN website: http://ssrn.com/abstract $=2588336$

Yousif, A., Niu, Z., Chambua, J., \& Khan, Z. Y. (2019). Multi-task learning model based on recurrent convolutional neural networks for citation sentiment and purpose classification. Neurocomputing, 335, 195-205. https://doi.org/10.1016/ j.neucom.2019.01.021

Yousif, A., Niu, Z., Tarus, J. K., \& Ahmad, A. (2017). A survey on sentiment analysis of scientific citations. Artificial Intelligence Review, 1-34. https://doi.org/10.1007/ s10462-017-9597-8

Žukauskas, P., Vveinhardt, J., \& Andriukaitienė, R. (2018). Philosophy and Paradigm of Scientific Research. In Management Culture and Corporate Social Responsibility (pp. 111-139). http:// dx.doi.org/10.5772/intechopen.70628 


\section{DAFTAR GAMBAR}

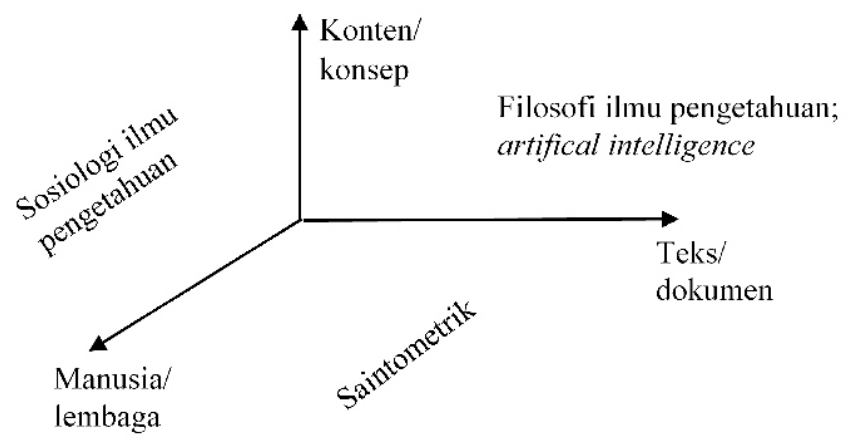

Gambar 1. Dimensi kajian kuantitatif sains (Sumber: Leydesdorff \& Milojevic, 2015)

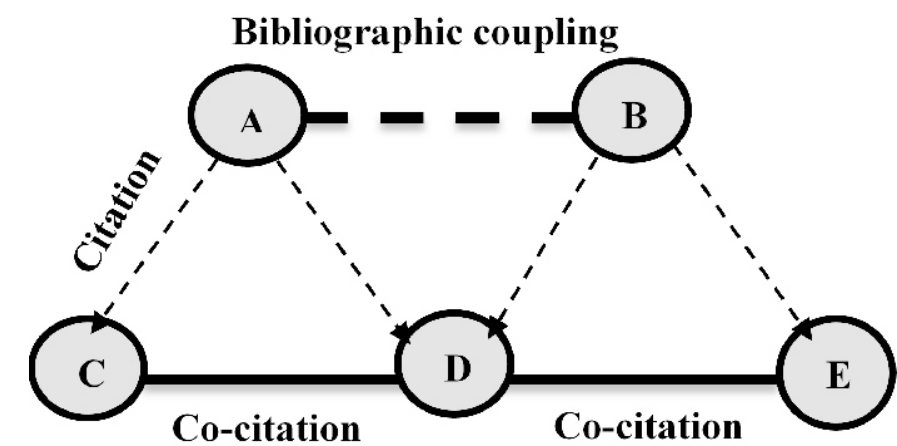

Gambar 2. Konsep analisis sitasi antar dokumen

(Sumber: Digambar ulang dari http://diging.github.io/tethne/doc/0.6.1-beta/tutorial.cocitation.html)

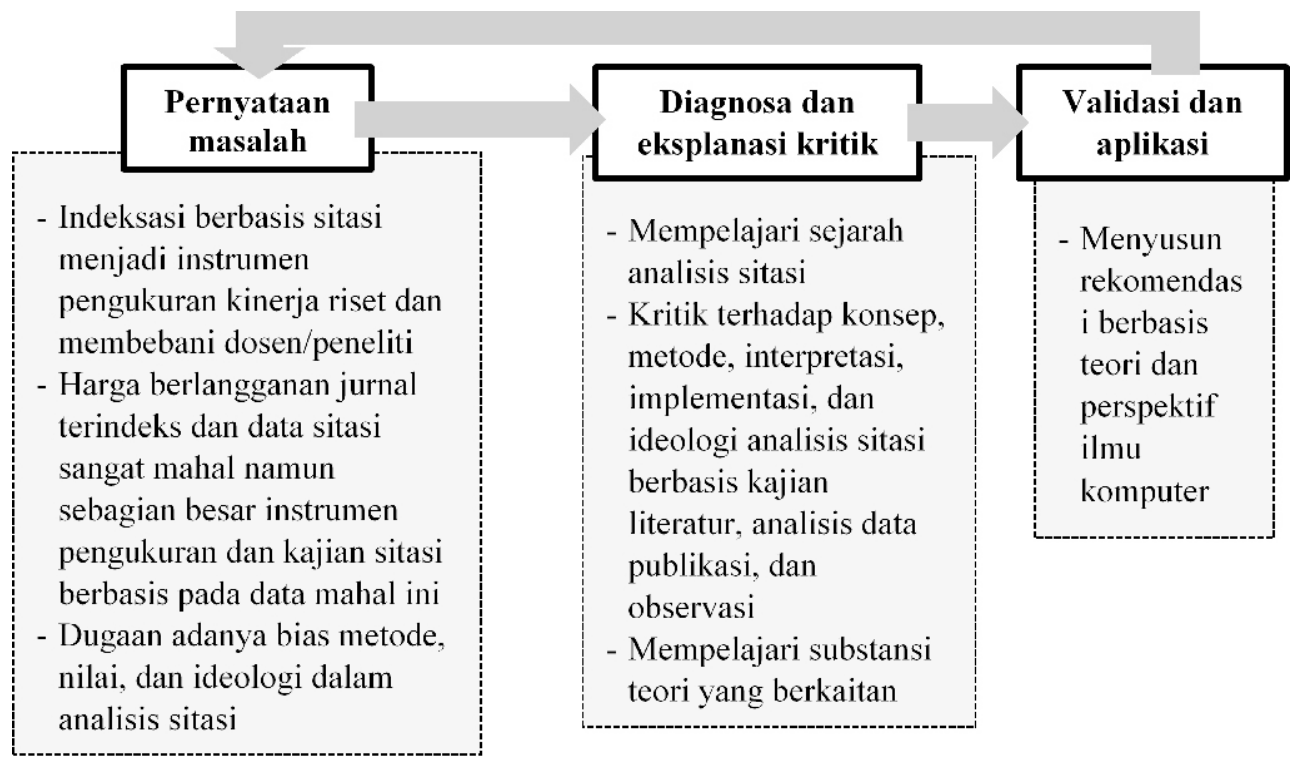

Gambar 3. Kerangka metodologi teori kritis (Sumber: Gambaran metodologi oleh penulis, 2019) 


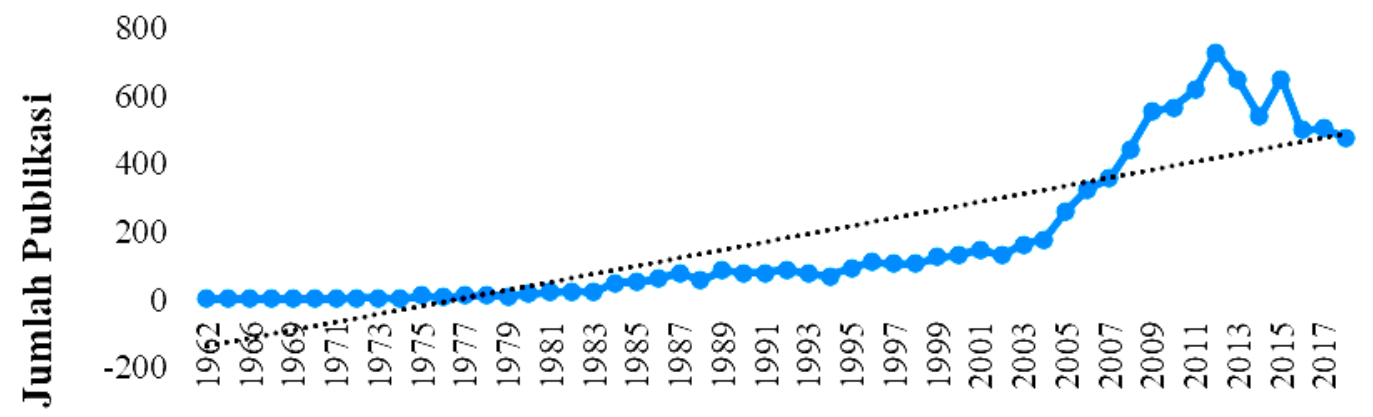

\section{Tahun}

Gambar 4. Pertumbuhan publikasi analisis sitasi di tingkat internasional (Sumber: Diolah dari data primer oleh penulis, 2019)

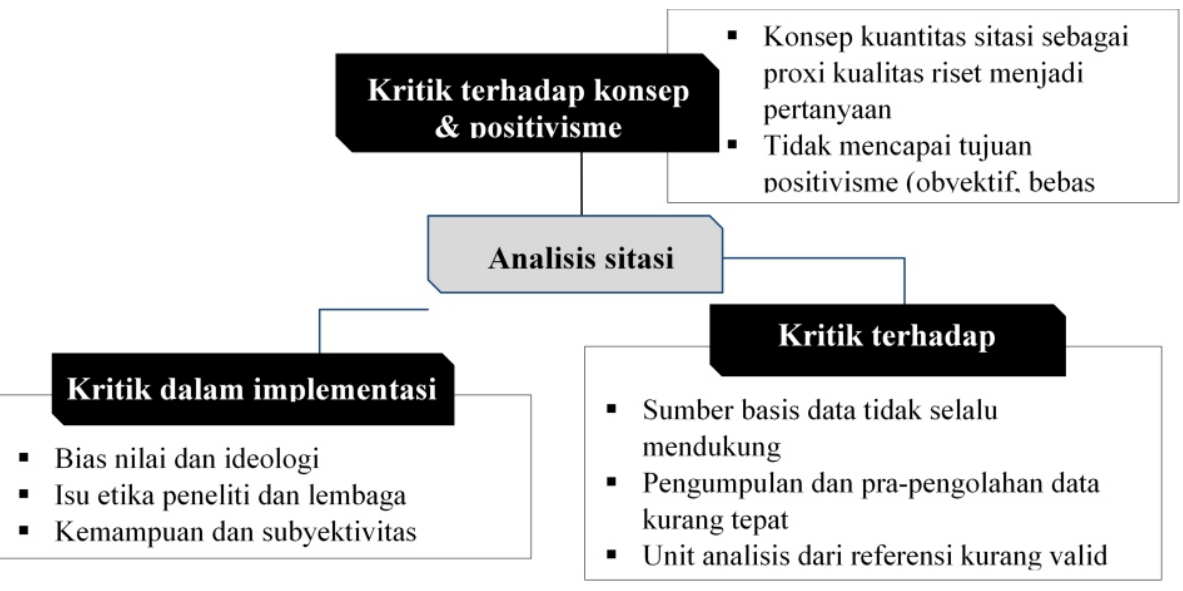

Gambar 5. Peta hasil telaah kritis analisis sitasi

(Sumber: Peta dibuat oleh penulis, 2019)

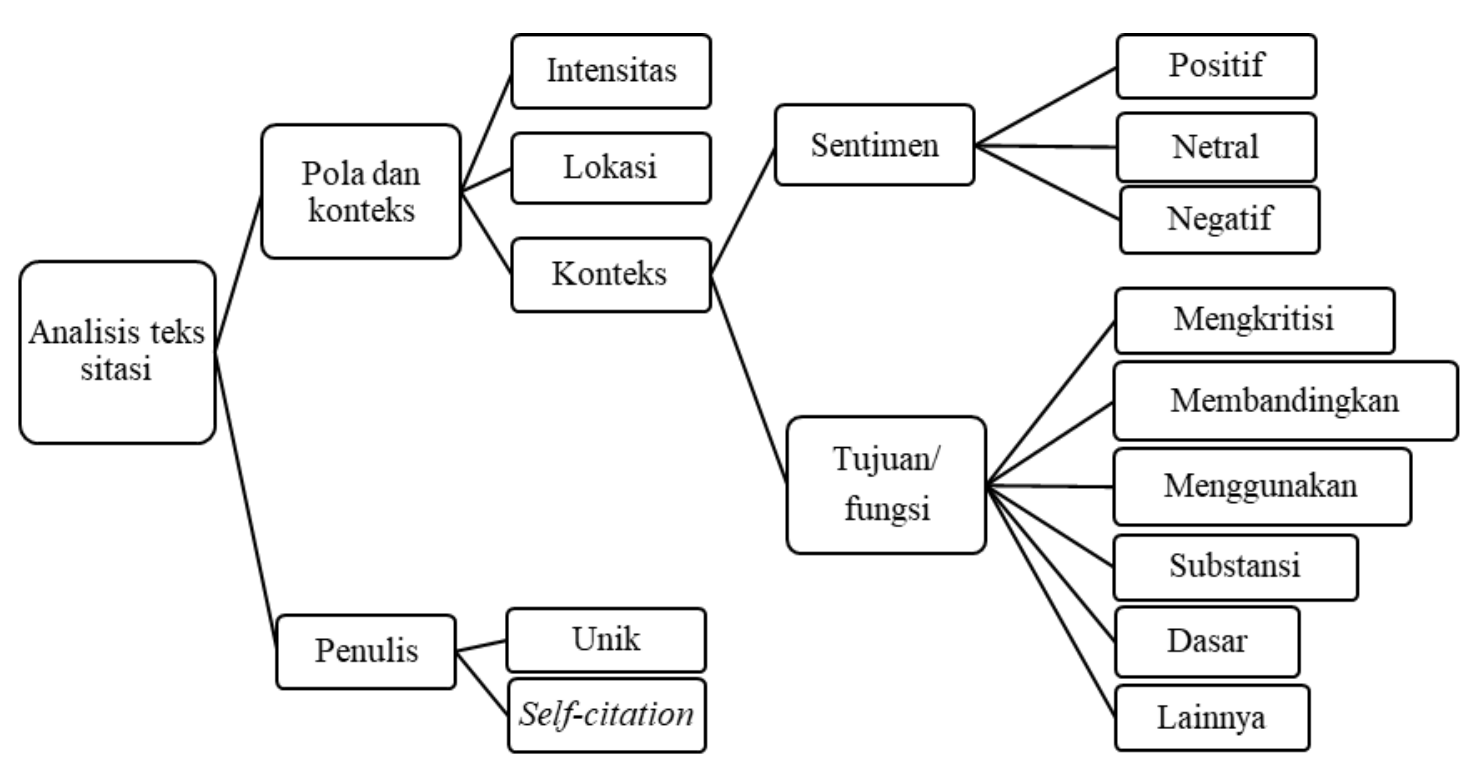

Gambar 6. Usulan perubahan variabel metode analisis sitasi berbasis ekstraksi teks (Sumber: Diagram dibuat oleh penulis, 2019) 